\title{
Privatizing Crime Control
}

Nick Tilley

Address

JDI

Department of Security and Crime Science

University College London

35 Tavistock Square

London WCIH 9EZ

UK

Email: $\underline{\text { n.tilley@ucl.ac.uk }}$

Cell: +44 (0) 7796241535

Work: +44 (0) 2031083190

Home: +44 (0) 1947605830

NOTE: Thanks are due to Gloria Laycock and Aiden Sidebottom, who read and commented on an earlier draft of this article and saved me from several errors. I am grateful also to anonymous reviewers whose suggestions for improvements to the article were invaluable. 


\section{Biography}

Nick Tilley is a professor in the Department of Security and Crime Science at UCL, emeritus professor of sociology at Nottingham Trent University, and an adjunct professor at Griffith Criminology Institute in Brisbane. He has published widely on policing, situational crime prevention, the international crime drop, and program evaluation methodology.

\section{ABSTRACT}

Crime problems largely result from opportunities, temptations, and provocations that have been provided unintentionally by those pursuing other private interests. There is a widespread notion that the state and its agencies can and ought to take full responsibility for crime control, and that there is, therefore, nothing that nonstate actors can or need to do. In practice, there is little that the state can do directly to address the opportunities, temptations and provocations for crime, but where crime control responsibilities have been accepted in the private sector, successful measures to reduce opportunities and temptations have been devised and adopted, preventing many crimes and reducing costs that would otherwise fall on the state as well as on victims. This article sets out the reasons why a shift in responsibility for crime prevention from the public to private sector can produce patterns of crime control that are both effective and socially desirable, albeit important roles remain for the public sector in stimulating and supporting such measures.

Keywords: privatized crime control; responsibilization; situational crime prevention; elegant security; DAPPER 
Some scholars seem to have an almost visceral dislike of security, situational crime prevention, and the notion that the private sector has responsibilities and capacities for delivering crime prevention that is in the public interest (for example Young 1986; Zedner 2003; Neocleous 2007).

Crime is deemed to be a function of criminality, which springs from individual or social pathology. Real prevention is achieved only by addressing such "root causes." Absent efforts to deal with these, little can be achieved beyond redistribution of the burdens of crime. The involvement of the private sector is liable, if anything, to shift that burden toward those who lack the resources to defend themselves. Situational measures risk being exclusionary and ugly, threaten privacy, jeopardize civil liberties, and blame victims.

This critique of situational crime prevention and privatized crime control suggests that crime prevention should be in the hands of the public sector, which alone can deal with crime and criminality in ways that are effective, equitable, and accord with public interests.

I have argued elsewhere that situational crime prevention has a radical core that challenges many conventional assumptions about the causes of crime and ways it can successfully be prevented and which also paves the way for delivering strategies that are equitable both in allocation of crime prevention resources and crime distribution outcomes. (Tilley 2016). Following up on that earlier article, here I argue that a shift in responsibility for crime prevention from the public to private sector can produce patterns of crime control that are both effective and socially desirable. I also argue, however, that such a shift requires substantial public sector activity and involvement. The argument proceeds through eight steps:

1. Many crime problems stem from opportunities, temptations, and provocations created unintentionally by those pursuing other private interests. 
2. There is little that the state can do directly to address causes of crime inadvertently supplied by the private sector.

3. In contemporary societies it is widely assumed that the state and its criminal justice agencies can and should control all crime.

4. The private sector can implement successful measures to control crime by reducing opportunities, temptations, and provocations.

5. The privatization of crime control has activated market mechanisms that have led to the development and application of effective and benign means of reducing opportunities and temptations to commit crime.

6. Privatizing crime control can be difficult, even where substantial crime prevention benefits may follow, especially where businesses are expected to bear the costs but not to benefit financially.

7. The public and voluntary sectors have important roles to play in informing, encouraging, enabling, underpinning, and extending the benign privatization of crime control.

8. The public sector's own efforts to regulate behavior can be criminogenic, inadvertently creating temptations and opportunities for crime. "Elegant" regulation aims to avoid these consequences.

\section{Many crime problems stem from opportunities, temptations, and provocations created} unintentionally by those pursuing other private interests.

Opportunity causes crime (Felson and Clarke 1998). Opportunities for crime come and go as side effects of developments with other purposes (Tilley 2012). The Internet furnishes one important, recent and rich new source of crime opportunities that was not 
previously available. Romance scams, for instance, are facilitated by online dating sites, which are run for commercial purposes and designed to meet the needs of those seeking partners. Dating sites are clearly popular in attracting many users who find them rewarding. The concentration of romance scams on a small proportion of those sites suggests that the ways in which websites are configured affect the risks to users (Sidebottom and Tilley 2017).

What goes for the Internet as a generator of romance scams in particular goes for many other types of private sector initiatives: a new innovation is made; it is commercially successful; it becomes very popular and it leads to crime opportunities, temptations, or provocations as a side effect (Pease 1997). These criminogenic side effects are concentrated on a particular subset of potential targets (Eck and Eck 2012; Tilley 2012).

Widely welcomed technological developments have often included the inadvertent supply of crime opportunities or provocations. Cars, carbines, credit cards, cell phones, laptops, and the Internet are all examples. In each case a substantial crime dividend has followed from advances that most have bought into (and from which entrepreneurs have profited), but that have created or improved opportunities for crime. These opportunities relate to the provision of attractive targets for thieves (cash, cars, carbines, credit cards, cell phones) and new resources facilitating the commission of crime (cash, cars, carbines, credit cards, cell phones, and the Internet). Likewise, many developments of commercial practices have been welcomed by consumers, but have again supplied opportunities for crime. Selfservice stores, nightclubs, and the complex financial instruments used by bankers are examples here, respectively facilitating or provoking theft, violence, and fraud.

\section{There is little that the state can do directly to address causes of crime inadvertently} supplied by the private sector. 
The state is unable directly to change the opportunities inadvertently created by private sector organizations. The state does not design or manufacture products that supply opportunities, nor does it manage private sector organizations whose practices and processes unintentionally provoke or create opportunities for crime.

Let us return to online dating sites and romance scams. There are estimated to be at least 1,400 online dating sites. Over a third of marriages in the United States originate in a meeting that followed an initial contact through such sites (Sidebottom and Tilley 2017). They therefore provide a valued service. They are no longer fringe affairs but are part of the mainstream. Yet for some users they furnish opportunities for scammers, who are able to sift through profiles to work out who might be open to grooming as potential targets. The sites also provide an opportunity for fraudsters to tailor their own profiles to give them the best chance of hooking the vulnerable and then to groom them over a sustained period. I

Romance scams are clearly emotionally and financially damaging for those who fall for them. They are also increasing in number - in England and Wales there was a 34 per cent increase in those reported between 2014 and 2015. The conditions enabling romance scams, however, are not in the hands of the state. There are, however, ways in which providers of internet dating sites can reduce opportunities. They can do so by setting ground rules for users, by alerting potential victims to their risks where they appear to be acting in ways that make them soft targets, by rooting out suspicious profiles and dating site usage to exclude some likely scammers or warn likely victims, and so on.

As indicated earlier romance scams are highly concentrated. In England and Wales, 42 per cent of reported romance scams were accounted for by one of 37 sites that reported one or more between 2013 and 2014. The most scammed site had 600 reported cases per million website visitors, the least presumably none, although the reported crime data clearly 
goes down only to one (Sidebottom and Tilley 2017). Only those running sites can put in place systems that minimize risks to their users.

3. In contemporary societies it is widely assumed that the state and, in particular, its criminal justice agencies can and should control all crime.

If we look back far enough, it is clear that measures preventing predation to self and closely related others go back to prehistory. Ecologists have identified diverse strategies that have evolved in plants and animals to reduce their immediate and long-term risks from others, thereby enabling them to survive. Strategies include camouflage, prickles, the reality (or appearance) of being poisonous or dangerous, stings, repulsive smells, and early warning systems that alert potential victims to risks (for examples, see Davies, Krebs, and West 2012).

As organized social life emerged, forms of co-operative protection from threats emerged and grew in significance. Some behaviors eventually came to be defined as "crimes" and their enforcement was put in the hands of the state, albeit citizens were often obliged to do their bit, as in "Hue and Cry," which made citizens in medieval times responsible for helping to apprehend suspects (see Zedner 2006). Over time, however, the roles and responsibilities assigned to private citizens diminished.

Engstad and Evans (1980) note that following the establishment of the metropolitan police in 1829, "The evolution of social and legal institutions has been accompanied by a gradual shifting of responsibility for crime control, from citizens to the police" (p. 140). Writing at a time when crime was rising rapidly in most Western countries, they add:

This shift in responsibility from the citizenry to the police has been accompanied by a shift in expectations with regard to their respective roles and competence as crime control agents. Here again, police have accepted increasing levels of public expectation. Indeed, the police 
have greatly overestimated the extent to which they could control crime and in so doing have greatly inflated public expectations. Moreover, raising citizens' expectations in regard to the role and competence of the police has had the effect of reinforcing citizens' acceptance of a diminished role and declining competence in crime control. (Engstad and Evans 1980, 14041)

Thus, crime control was gradually transferred from private to public bodies, leading to a form of "de-responsibilization.",

The assumption that the state is both responsible for and competent in crime control, coupled with the price paid for these services through our taxes, residualizes citizen responsibility for crime control. Although many take precautions to protect themselves, citizens largely become adjuncts of state crime control, simply acting as voluntary witnesses or reporters of crime, or passing on suspected malefactors to competent state authorities.

Ekblom (1986) describes a business sector response to a crime problem rooted in the then-prevailing assumption about state responsibility for crime control and the role of the private sector that follows. His study concerned shoplifting at HMV, a large store in London's Oxford Street that sold audio-cassettes, records, videotapes, computers and computer tapes. Stores such as these had (and still have) an interest in preventing these crimes because of the consequential losses.

HMV was a popular target for shoplifters and in light of that the store employed six uniformed security guards and five plain-clothes store detectives. The idea was to detect offenders and pass them to the police. In one respect HMV's security staff were successfulin 1985 they accounted for 420 of 1,074 arrests (39 percent) for shoplifting dealt with by the Shoplifting Unit at the local police station, which covered a large number of major stores in London's West End. 
HMV's approach to crime control treated the state as the body ultimately responsible for crime prevention. HMV's job was only to identify offenders, hand them over to the police, and be witnesses if needed in courts of law. They were, essentially, adjuncts to the state as the authority that could control crime.

As the next section notes, there is extensive and compelling evidence that situational contingencies in the hands of the private sector can be altered in ways that prevent crimes. In HMV, however, this was not the approach adopted. The store's arrest policies assumed that crime control had to do with dealing with offenders, who were passed on to the police. There was no evidence, however, that those arrested were hardened criminals rather than those responding to the opportunities provided by the shop.

\section{The private sector can implement successful measures to control crime by reducing} opportunities, temptations, and provocations.

There are many examples of alterations in situational contingencies that have prevented crimes (Guerette 2009; Clarke and Bowers 2017). Here are examples relating to car theft, shop theft, and crime and disorder in and around clubs and pubs.

a) Car theft. Drops in car crime since the early 1990s resulted in large part from improvements to their inbuilt security, notably the installation of electronic immobilizers but also high-quality window and door locks, central locking, and alarms (Farrell et al. 2011, Farrell, Tseloni, and Tilley 2011; Farrell, Tilley, and Tseloni 2014; Brown 2013). There is also some evidence that improvements in the security of parking lots reduced car theft within them (Smith, Gregson, and Morgan 2003). Moreover, action to reduce "debut crimes" such as car theft may have 
produced wider crime prevention benefits by inhibiting the onset of criminal careers (Farrell, Laycock, and Tilley 2015).

b) Shop theft. Overall levels of shop theft have been falling in many countries, as measured by well-conducted commercial victimization surveys. Hopkins and Gill (2017), for example, report that in England and Wales the Commercial Victimisation Survey found that between 1993 and 2015, the prevalence of shop theft fell from 470 to 220 and the incidence rate from 22,286 to 8,862 per 1,000 premises. There is growing evidence that shops themselves can and have reduced their vulnerability by alterations in their shop layouts, displays, and use of security measures such as electronic and dye tags (DiLonardo and Clarke 1996; Farrington et al. 1993; Clarke and Petrossian 2013; Sidebottom et al. 2016).

c) Crime and disorder in and around clubs and pubs. Some bars, nightclubs, and entertainment districts have adopted broad strategies as well as specific measures to reduce violence and harms caused by violence (Homel et al. 1997; Macintyre and Homel 1997; Maguire and Nettleton 2003). Layout (for example to avoid collisions), management practices (for example policies on serving drinks), and the replacement of annealed glass (which breaks into splinters and can cause serious disfiguring injuries in fights) with plastic or toughened glass have all been directed at reducing crime associated with bars and the harms that follow. Shared codes of conduct have been developed and enforced in some problem areas requiring bars to maintain standards and compete on the basis of service rather than the price of alcohol, with the aim of reducing crime and disorder.

In each case, the private sector has accepted some responsibility (albeit often reluctantly) for controlling the crime it unintentionally produces, using a range of techniques that reduce opportunity and temptation (especially in the case of car theft and shoplifting) and 
provocation (especially in the case of bars, clubs, and entertainment districts). Trends in all cases suggest that the measures adopted have been successful.

\section{The privatization of crime control has activated market mechanisms that have led to the} development and use of effective and benign means of reducing opportunities and temptations to commit crime.

Shearing and Stenning (1992) describe benign but pervasive private controls at Disney World. As they put it:

Control strategies are embedded in both environmental features and structural relations. In both cases control structures and activities have other functions which are highlighted so that the control function is overshadowed. Nonetheless, control is pervasive. For example, virtually every pool, fountain, and flower garden serves as both an aesthetic object and to direct visitors away from, or towards, particular locations. Similarly, every Disney Productions employee, while visibly and primarily engaged in other functions, is also engaged in the maintenance of order. The integration of functions is real and not simply an appearance: beauty is created, safety is protected, employees are helpful. The effect is, however, to embed the control function into the "woodwork" where its presence is unnoticed but its effects are ever present. (Shearing and Stenning 1992, 251)

Shearing and Stenning go on to note that, 'While this new instrumental discipline is rapidly becoming a dominant force in social control it is as different from the Orwellian totalitarian nightmare as it is from the carceral regime..." (Shearing and Stenning 1992, 254). Disney World clearly has commercial interests in inconspicuous but effective control that enables its many visitors to enjoy themselves. The business would be less profitable if it risked losing customers fearful that their visits might be blighted by antisocial behavior from 
others. The whole experience needs to be fun, and this requires order that is produced apparently spontaneously rather than by overt interventions by specialist or uniformed guards.

The attributes of benign security of the kind provided at Disney World are captured in the acronym DAPPER (Tilley et al. 2015). DAPPER security is "elegant.” DAPPER refers to Default (Disney World's default state is that it is orderly and secure for visitors), Aesthetic (the security provided is unobtrusive and woven into the fabric of Disney World), Powerful (there is negligible disorder at Disney World, despite the large number of people there and the long lines for many attractions); Principled (the security does not threaten civil liberties and is acceptable by all), Effortless (Disney World's security requires no effort by visitors and is incorporated into other parts of design and function that have other main purposes), and Rewarding (the benefits of the security exceed costs to both Disney World and its clients).

DAPPER attributes for elegant security were first highlighted in relation to vehicle security, where a range of technological developments improving security have played a major part in the steep fall in car theft in many countries (Farrell et al. 2011, Farrell, Tseloni, and Tilley 2011). The car's default state is that it is secure (central locking doors, windows, and trunk; priming of alarm and of electronic immobilizer on leaving the vehicle; lock nuts to wheels; automatic folding wing mirrors; audio system and satnav components distributed through the vehicle, and so on). The additional security now incorporated into the car does not reduce any aesthetic qualities it has. The security measures are powerful (they are very effective). The devices incorporated into vehicles are principled (they are acceptable to all and do not reduce civil liberties). The security is effortless (the driver has to do less and less for the vehicle to be left in a secure state). Finally, the inbuilt security is rewarding (the 
additional costs of inbuilt security are small in relation to the total cost of vehicles and the benefits in terms of reduced crime risk high).

Table 1 tries to distinguish more from less DAPPER security as it relates to car theft, shop theft, and crimes in and around bars. In each case, it could be expected that customers and clients would prefer the DAPPER alternatives.

\section{TABLE 1}

\section{More and Less Elegant Security for Cars, Shops, and Licensed Premises}

[table 1 about here]

Dependency on the state to control crime remains rational so long as the risks of and losses from crime levels remain relatively low. Once these risks and losses (or perceptions of them) reach a certain level then there are incentives to take private action. The state may still be deemed responsible, but its competency comes into question, at which point private action becomes more likely. Moreover, once a sufficient market for security develops, competition between providers should occur and with that competition providers will attempt to outdo one another in terms of the effectiveness, price, and attractiveness of their products and services.

\section{Privatizing crime control can be difficult, even where substantial crime prevention} benefits may follow, especially where businesses are expected to bear the costs but not to benefit financially.

As Dennis Challinger, writing from Coles Myer, a major Australian retailer, succinctly put it at the start of a paper asking if crime prevention will ever be a priority for business, "Businesses exist to make profits" (Challinger 1997, 35). Even if profitability is not the sole concern of a business, it is a sine qua non for its long-term survival. Hence, whatever the preferences of those working within a business (and acknowledging that many might 
prefer to behave responsibly) unless an eye is kept on profitability the company will wither. In a competitive situation, if one company incurs costs for prevention that others do not and those costs are not eventually covered by improved returns then the company puts itself at a disadvantage. These commercial realities explain why measures are sometimes adopted or not adopted and why strategies may be needed to encourage companies to adopt preventive strategies.

Even when the direct victim of unintended crime consequences is the business itself, for example with shop theft, private control measures may not be taken. There are three main reasons for inaction. First, ignorance about loss: shops suffer shrinkage but often do not know its exact source. Apparent shrinkage can be created by customer theft; staff theft; short deliveries; spoiled, damaged or defective goods; or accounting errors (Beck 2016). Misattribution or misunderstanding of the sources of shrinkage may lead either to failure to adopt control strategies or the implementation of misdirected ones. Second, ignorance about means of prevention: the business may not know how to control crime effectively. Effective methods of controlling crime are contested and finding what works can be tricky. The "fundamental attribution error" (Ross and Nisbett 2011), is widely held, according to which (mis)behavior is over attributed to characteristics of perpetrators (about which commercial organizations can do little or nothing) and under-attributed to immediate situations (about which commercial organizations can do a great deal). Third, interests: taking a hit from crime may be less costly than preventive measures to control it. For example, to maximize sales, the layout of the shop and presentation of goods may facilitate crime by making it readily available for the customer to handle. The perceived benefits (increased profit) from the increased sales may outweigh the perceived costs of its control (Sidebottom et al. 2016).

Failure of businesses to act where a third party is the victim is easier to understand. Why would they incur costs they could avoid in a competitive environment? This likely 
explains why motor manufacturers were reluctant to improve security to their vehicles even when it was known that they were frequent targets of crime.

Notwithstanding commercial interests, it would be a mistake to assume that businesses will act to prevent crime only if doing so directly contributes to their economic success. Ignorance may still play a part. One study found that supermarkets were hot spots for theft of purses from older women who routinely left them in their shopping carts as they walked round the aisles. One store in particular had little idea this was happening (Sidebottom, Guillaume, and Archer 2012). The business had no vested interest in reducing the risks to third parties. On being told of the problem, however, the store agreed to trial the use of trollies adapted to provide safe storage for purses. Although the store may have hoped that positive publicity would increase customers, there is no direct evidence that this was the case. Rather, the store was persuaded that it should bear some costs in trying to make vulnerable customers safer. ${ }^{\text {ii }}$ The next section discusses various ways in which benign private sector efforts at crime control can be encouraged in practice.

7. The public and voluntary sectors have important roles to play in informing, encouraging, enabling, underpinning, and extending the benign privatization of crime control.

Even though the privatization of crime control can deliver effective and elegant security, it will not necessarily do so. There are important roles for the state and voluntary sectors in fostering and underpinning the development of benign privatized controls.

Potential dangers and downsides of privatizing crime control include:

1. Displacement of crime from the rich to the poor. Privatized control incurs costs more easily afforded by the better than the worse off. Crime may migrate from the relatively rich to the relatively poor. Some measures to reduce domestic burglary, for 
example CCTV and advanced alarm systems, are costly and tend to be installed by the better off. If displacement occurs it may be to those unable so easily to afford such measures.

2. Social exclusion. The better off withdraw to their safe enclaves from which the poor are kept out. Moreover, those who appear out of place are prevented from entering semi-public places such as shopping malls in the interests of increasing the comfort of better off shoppers.

3. Guns and violence. Whereas privately owned handguns may reduce risks of some forms of crime by providing deterrence, their widespread ownership creates opportunities for deliberate shootings and risks of accidental ones, with fatal consequences.

4. Fortresses. Many forms of private security, such as window bars, are ugly and spoil the appearance of cities.

5. Noisy alarms. Some private security devices create their own nuisances, for example malfunctioning alarms.

6. Skewed use of public crime control resources. As with the HMV example cited earlier private crime controls can produce demands on the public police. The opportunity cost is their nonavailability for other purposes.

7. Ineffective measures. Those hoping to profit from their crime prevention devices are apt to over claim their effectiveness in the interests of sales. Moreover, buyers are attracted by cheap but inelegant measures where the state is expected to control crime and private security is purchased grudgingly.

8. Anxiety about crime. Selling security depends on creating demand, which deliberately or otherwise creates exaggerated fears of crime, which in turn may lead some citizens to restrict their social lives. 
9. Victim blaming. Those responsible for crimes are the offenders themselves.

Bestowing responsibility on potential victims for self-protection, implicitly assigns them responsibility for crimes committed against them.

10. Buck passing. It is the responsibility of the state in general and the police in particular to prevent crime. Shifting responsibility for crime control to others involves evasion by the public body created to perform the task.

A dystopian vision is, thus, easy to produce. Private security protects the rich with ugly, high walls, heavy-handed security guards, and firearms. The rich mobilize the machinery of the state to supplement their private security. The poor are physically and symbolically excluded from some activities and places, for example wandering in smart shopping malls or entering fashionable suburbs. Beyond the safe enclaves of the relatively rich lie the badlands. Here, the stronger prey on the weaker. In obviously dangerous public spaces, never entered by the better off, fearful and vulnerable citizens prey on one another.

Given the argument so far that a) private controls can be well targeted, effective, and benign, b) many crimes are costly byproducts of successful private enterprises, and that c) the state is poorly placed to deliver effective controls over them, we need to work out what the state can do to foster more benign (DAPPER), and avert more malign, preventive approaches. The following is a tentative list of roles for the state and voluntary sectors.

First, the state must set the rules that constitute crime. Many citizens and corporate bodies obey the law simply because it is the law.

Second, the state comprises a legitimate guarantor that the risk from committing a crime can lead to real penalties. Increasing risk to possible offenders is one major technique for reducing crime opportunity. This is meaningful only if backed ultimately by the state. 
Third, risks of victimization may be unknown either by those who face them or by those who inadvertently create them. The public sector has an important role to play in attempting accurately to estimate crime risks and to ensure that those who create them or face them understand those risks so that they can develop ways to reduce them. Laycock (2004), for example, shows how research from the British Home Office identified which models of car were at greatest risk of theft, to indicate where improvements in security were most pressing. ${ }^{\text {iii }}$ There are other sources of this information also. For example, consumer and private research groups have provided information on crime risks that citizens and organizations can use to target crime control measures.

Fourth, those who face and create risks may not know what they can do to reduce them. Although they are not the sole source of such information, state organizations are well placed to assess the effectiveness of crime control measures. Consumer organizations and independent research agencies can also contribute to this body of knowledge.

Fifth, the state restricts what can be done by way of private crime control. In effect, it sets rules for what can and cannot be done in an attempt to avert private controls that are themselves harmful. If these rules are to be evidence based then publicly funded research is preferable to privately funded work where vested interests risk undermining the independence and hence reliability of findings.

Sixth, the state has a range of tools through which it can promote private crime control measures, some of which are more coercive than others. Hardie and Hobbs (2005) note that the most obvious means—regulation and self-interest—do not exhaust possibilities. External pressure groups, peers, the press and investors, for example, may also motivate action (Hardie and Hobbs 2005, 103-5). Although profitability can often be the ultimate concern, those in the private sector sometimes take actions simply because they become persuaded that it is the right thing to do. 
A general principle seems to have emerged for encouraging attention to unintended, socially costly side effects of private actions, such as crime. This is that cooperation is preferable to coercion (see for example Scott and Goldstein 2005; Bemelmans-Videc, Rist, and Vedung 1998; Ayres and Braithwaite 1992; Eck and Eck 2012). Other things being equal, cooperation is faster, better targeted, cheaper, less liable to provoke resistance, more likely to lead to increasingly elegant solutions to problems, and less likely to provoke further unwanted unintended consequences.

Ayres and Braithwaite (1992) show formally how and why graduated pressure works more effectively than application of a big stick, although the big stick still matters. It is widely accepted that cooperation is more likely if there is an iron fist in the velvet glove, especially where there are strong vested interests at stake. In other words, the availability, ultimately, of state means to coerce the private sector into reducing or eliminating its production of negative externalities such as crime, can motivate cooperation, which is preferable because it is less costly to both parties. Coercion is best left, where needed, to the recalcitrant few.

Exploiting the types of motive mentioned by Hardie and Hobbs, both local and national government (in conjunction with consumer organizations and the mass media) have a range of ways to elicit private sector efforts to control crime short of the creation and enforcement of regulations. However, where costs are borne by one business but not others in a market, the business taking on those costs is to that extent at a competitive disadvantage. Even if any given individual in a private enterprise would rather act altruistically the logic of competition puts limits on what can be achieved.

Where a market develops for security, it can produce elegant solutions. Again, consider car crime. The insurance industry in the United States has used data on claims to identify which models of vehicles are associated with the largest human and economic losses, 
including those from theft (Hazelbaker 1997). The Highway Loss Data Institute lists the models with highest and lowest claim rates by type of vehicle, for example very large pickup, large luxury SUV, small SUV etc. ${ }^{\text {iv }}$ This activity has contributed to a spate of innovations in car design, leading to increasingly elegant, DAPPER security measures that are built into vehicles. Once a market develops, there are incentives for continuous improvements that will be effective and appeal to consumers. Unless kick-started by third party prompts, such as those that can be used by governments, these market processes are unlikely to be engaged. Eck has highlighted benefits from encouraging the achievement of crime control ends rather than the adoption of specific means. Doing so is a way of stimulating (private) efforts to work out how to achieve crime prevention outcomes where the specific means are not already well established or may need to be tailored to particular contexts (see Eck and Eck 2012; Eck 2017).

That does not mean there are no circumstances when regulation is beneficial and may be welcomed by those in the private sector. For instance, suppose costs are incurred by those businesses that take action to reduce a given negative externality such as crime. In this situation, other businesses, which fail to do so, are at a competitive advantage. Here a universal requirement may be preferable to those inclined to do the right thing. This occurred when there was a European directive requiring that cars be fitted with an electronic immobilizer that met minimum standards. In the case of electronic immobilizers, a strong known specific measure was at issue, whose universal application might eventually engender a form of herd immunity from crime but where free riders might be tempted to avoid the costs involved. In these circumstances, it may make sense to require universal measures from the private sector. 
8. The public sector's own efforts to regulate behavior can be criminogenic, inadvertently creating temptations and opportunities for crime. "Elegant" regulation would aim to avoid these consequences.

States themselves sometimes inadvertently create opportunities for crime. Motorcar registration systems, for example, may take a form that facilitates the easy alternation of the identity of a stolen car, which can then be sold (Webb, Smith, and Laycock 2004). Prisons run by the state may be designed and run in ways that unintentionally enable or provoke crimes among inmates and between inmates and staff (Wortley 2002). Hospitals may be designed and operated in ways that inadvertently foster costly crime opportunities or provocations (Smith 1987). Regulatory regimes may again inadvertently provoke criminal behaviors (Ayres and Braithwaite 1992). In each case, government is able directly to act in ways that minimize provocation and opportunity. Indeed, there is a literature on ways in which unintended opportunities and provocations can be reduced (see Savona 2017). As with crime prevention as it relates to car crime, the direction of travel would most sensibly be toward elegance albeit here governments are able to act directly.

\section{Conclusion}

This article has sketched an argument in favor of privatizing crime control through reducing crime opportunities, temptations, and provocations. This is not to say there is no role for the public sector. As indicated, the public sector has an important part to play in extending and fostering benign private controls and in attending to crime opportunities it may itself unintentionally supply.

The case made here builds on Freilich and Newman's argument in favor of using situational crime prevention to deal with crime problems at the local and national levels (Freilich and Newman 2016). At both levels, there is a crucial role for private crime control. 
However, re-responsibilizing third parties for crime control will often be difficult. Moreover, responsible re-responsibilization (where third parties apply only benign measures) consists of a further challenge. Heavy-handed regulation may not be the best first method to choose in encouraging the private sector to devise and implement effective and ethical private crime controls. There is much to be said in favor of stimulating a market, which will incentivize innovation and the voluntary application of elegant forms of crime control. This article provides a modest step toward thinking through what may be needed to achieve this.

\section{References}

Ayres, Ian and, John Braithwaite. 1992. Responsive regulation: Transcending the deregulation debate. Oxford: Oxford University Press.

Beck, Adrian. 2016. Beyond shrinkage: Introducing total retail loss. Arlington, VA: RILA. Bemelmans-Videc, Marie-Louise, Ray. Rist, and Evert Vedung, eds. 1998. Carrots, sticks, and sermons: Policy instruments and their evaluation. New Brunswick, NJ: Transaction Publishers.

Brown, Rick 2013. Reviewing the effectiveness of electronic vehicle immobilisation: Evidence from four countries. Security Journal. doi: 10.1057/sj.2012.55.

Challinger, Dennis 1997. Will crime prevention ever be a business priority? In Business and crime prevention, eds. Marcus Felson and Ronald Clarke, 35-55. Monsey, NY: Criminal Justice Press.

Clarke, Ronald, and Kate Bowers. 2017. Seven misconceptions of situational crime prevention. In Handbook of crime prevention and community safety, 2nd ed., eds. Nick Tilley and Aiden Sidebottom, 109-42. London: Routledge.

Clarke, Ronald, and Gohar Petrossian. 2013. Shoplifting. Problem-Oriented Guides for Police No. 11, 2nd ed. Washington, DC: Office of Community Oriented Policing Services.

Davies, Nicholas, John. Krebs, and Stuart West. 2012. An introduction to behavioural ecology. Chichester: John Wiley \& Sons.

DiLonardo, Robert., and Ronald Clarke. 1996. Reducing the rewards of shoplifting: An evaluation of ink tags. Security Journal 1 (7): 11-14.

Eck, John 2017. Regulation to prevent crime. In Handbook of crime prevention and community safety, 2nd ed., eds. Nick Tilley and Aiden Sidebottom, 294-316. London: Routledge.

Eck, John, and Emily Eck. 2012. Crime place and pollution. Criminology \& Public Policy 11 (2): 281-316.

Ekblom, Paul 1986. The prevention of shop theft. Crime Prevention Unit Paper 5. London: Home Office.

Engstad, Peter, and John Evans. 1980. Responsibility, competence and police effectiveness in crime control. In The effectiveness of policing, eds. Ronald Clarke and Michael Hough, 139-62. Farnborough, Hants: Gower. 
Farrell, Graham, Gloria Laycock, and Nick Tilley. 2015. Debuts and legacies: The crime drop and the role of adolescence-limited and persistent offending Crime Science 4: 16. DOI 10.1186/s40163-015-0028-3

Farrell, Graham, Nick Tilley, and Andromachi Tseloni. 2014. Why the crime drop? Crime and Justice 43:421-90.

Farrell, Graham, Andromachi Tseloni, Jen Mailley, and Nick Tilley. 2011. The crime drop and the security hypothesis. Journal of Research in Crime and Delinquency 48 (2): $147-75$.

Farrell, Graham, Andromachi Tseloni, and Nick Tilley. 2011. The effectiveness of vehicle security devices and their role in the crime drop. Criminology and Criminal Justice 11 (1): 21-35.

Farrington, David., Sean Bowen, Abigail Buckle, Tony Burns-Howell, John Burrows, and Martin Speed. 1993. An experiment on the prevention of shoplifting. Crime Prevention Studies 1:93-119.

Felson, Marcus and Ronald V. Clarke. 1998. Opportunity makes the thief. Police Research Series Paper 98, Policing and Reducing Crime Unit. London: Home Office.

Freilich, Joshua, and Graeme Newman. 2016. Transforming piecemeal social engineering into "grand" crime prevention policy: Towards a new criminology of social control. Journal of Criminal Law and Criminology 105 (1): 203-32.

Garland, David 2001. The culture of control. Oxford: Oxford University Press.

Guerette, Rob 2009. The pull, push and expansion of situational crime prevention evaluation: An appraisal of thirty-seven years of research. In Evaluating crime reduction initiatives, eds. Johannes Knutsson and Nick Tilley, 29-58. Monsey, NY: Criminal Justice Press.

Hardie, Jeremy, and Ben Hobbs. 2005. Partners against crime: The role of the corporate sector in tackling crime. In Designing out crime from products and systems, eds. Ronald Clarke and Graeme Newman, 85-140. Monsey, NY: Criminal Justice Press.

Hazelbaker, Kim 1997. Insurance industry analyses and the prevention of motor vehicle theft. In Business and crime prevention, eds. Marcus Felson and Ronald Clarke, 283-93. Monsey NY: Criminal Justice Press.

Homel, Ross, Marg Hauritz, Richard Wortley, Gillian McIlwain, and Russell Carvolth. 1997. Preventing alcohol-related crime through community action: The Surfers Paradise Safety Action Project. In Policing for prevention: Reducing crime, public intoxication and injury crime prevention studies, ed. Ross Homel, 35-90. Monsey NY: Criminal Justice Press.

Hopkins, Matt, and Martin Gill. 2017. Business crime and crime prevention: Emerging debates and future challenges. In Handbook of crime prevention and community safety, 2nd ed., eds. Nick Tilley and Aiden Sidebottom, 373-93. London: Routledge.

Laycock, Gloria 2004. The UK car theft index: An example of government leverage. In Understanding and preventing car theft, eds. Michael Maxfield and Ronald Clarke, 25-44. Monsey NY: Criminal Justice Press.

Macintyre, Stuart, and Ross Homel. 1997. Danger on the dance floor: A study of interior design, crowding and aggression in nightclubs. In Policing for prevention: Reducing crime, public intoxication and injury crime prevention studies, ed. Ross Homel, 91113. Monsey NY: Criminal Justice Press.

Maguire, Mike, and Hilary Nettleton. 2003. Reducing alcohol-related violence and disorder: An evaluation of the "TASC" project. Home Office Research Study 265. London: Home Office.

Neocleous, Mark 2007. Security, commodity, fetishism. Critique 35 (3): 339-55. 
Pease, Ken 1997. Predicting the future: The roles of routine activities and rational choice theory. In Rational choice and situational crime prevention, eds. Graeme Newman, Ronald Clarke and Shlomo Shoham, 233-45. Aldershot: Dartmouth.

Ross, Lee, and Richard Nisbett. 2011 The person and the situation. London: Pinter and Martin.

Savona, Ernesto 2017. Proofing legislation against crime as situational prevention measure. In Crime prevention in the $21^{\text {st }}$ century, eds. Benoit Leclerc and Ernesto Savona, 24774. Switzerland: Springer.

Scott, Michael, and Herman Goldstein. 2005. Shifting and sharing responsibility for public safety problems. Washington, DC: US Department of Justice, Office of Community Oriented Policing Services.

Shearing, Clifford, and Phillip Stenning. 1992. From the panoptican to Disney World: The development of discipline. In Situational crime prevention: Successful case studies, ed. Ronald Clarke, 249-55. New York, NY: Harrow and Heston.

Sidebottom, Aiden., Peter Guillaume, and Tony Archer. 2012. Supermarket carts to reduce handbag theft. In Designing out crime from products: Towards research-based practice, ed. Paul Ekblom, 201-28. Boulder, CO: Lynne Rienner.

Sidebottom, Aiden, Amy Thornton, Lisa Tompson, Jyoti Belur, Nick Tilley, and Kate Bowers. 2016. A systematic review of tagging as a method to reduce theft in retail environments. Crime Science 6:7.

Sidebottom, Aiden and Nick Tilley. 2017. Designing systems against crime. In Handbook of crime prevention and community safety. 2nd ed., eds. Nick Tilley and Aiden Sidebottom, 254-73. London: Routledge.

Smith, David G., Mick Gregson, and James Morgan. 2003. Between the lines: An evaluation of the secured car park award scheme. London: Home Office.

Smith, Lorna 1987. Crime in hospitals: Diagnosis and prevention. London: Home Office.

Tilley, Nick. 2012. Crime reduction: Responsibility, regulation, and research. Criminology and Public Policy 11 (2): 361-78.

Tilley, Nick. 2016. Middle range radical realism for crime prevention. In What is to be done about crime and punishment towards a "public criminology", ed. Roger Matthews, 89-122. London: Palgrave Macmillan.

Tilley, Nick, Graham Farrell, and Ronald Clarke. 2015. Target suitability and the crime drop. In The criminal act: The role and influence of routine activities theory, eds. Martin Andresen and Graham Farrell, 59-76. London: Palgrave Macmillan.

Webb, Barry, Melissa Smith, and Gloria Laycock. 2004. Designing out crime through vehicle licensing and registration systems. In Understanding and preventing car theft, eds. Michael Maxfield and Ronald Clarke, 67-84. Monsey NY: Criminal Justice Press.

Wortley, Richard 2002. Situational prison control: Crime prevention in correctional institutions. Cambridge: Cambridge University Press.

Young, Jock 1986. The failure of criminology: The need for a radical realism. In Confronting crime, eds. Roger Matthews and Jock Young. London: Sage.

Zedner, Lucia 2003. Too much security? International Journal of the Sociology of Law $31: 155-84$.

Zedner, Lucia 2006. Policing before and after the police: The historical antecedents of contemporary crime control. British Journal of Criminology 46 (1): 78-96.

Notes 
i David Garland (2001) introduced the concept of "responsibilization" to describe recent efforts to mobilize noncriminal-justice agencies and organizations into control crime. It might be more accurate to say that such recent efforts consists of a movement toward re-responsibilization.

ii The cost of the modified carts used in the trial was borne by their manufacturers, who presumably did have a commercial interest in developing a new design for which there could be a market.

iii This information was used to put pressure on manufacturers to build security into vehicles.

${ }^{\text {iv }}$ http://www.iihs.org/iihs/news/desktopnews/ford-f-250-has-highest-theft-rate-of-any-2010-12-vehicle-cadillacescalade-drops-to-6th-on-list-after-years-on-top. 